\title{
COMPARING CROSS LAMINATED TIMBER WITH CONCRETE AND STEEL: A FINANCIAL ANALYSIS OF TWO BUILDINGS IN AUSTRALIA
}

\author{
Dylan S. Cazemier \\ University of New South Wales, Faculty of Built Environment \\ Dylan.cazemier@gmail.com
}

\begin{abstract}
This research paper undertakes a comparative financial analysis of the performance of a Cross Laminated Timber (CLT) apartment building with a concrete and steel apartment building constructed in Australia. A product known as CLT has been found to be an effective alternative form of construction to building with the more traditional materials of concrete and steel. CLT can assist in reducing carbon emissions through carbon sequestration. Respective revenue, time and cost variables are calculated, analysed and compared per development. Financial modelling of these variables results in; Development Margin, Development Profit, Return on Equity (ROE) and Equity Internal Rate of Return (IRR). These figures are performance indicators used to appraise the development. The study supports the economic benefits when comparing CLT to concrete and steel construction. It is concluded that building with CLT may result in less development profit and margin, but an increased Equity IRR due to a reduced investment timeline.
\end{abstract}

Keywords: CLT, Concrete, Steel, Financial model, Sustainability, Cross laminated timber.

\section{INTRODUCTION}

\subsection{Background}

The world is in a current environmental crisis; the climate is changing due to human induced emissions of greenhouse gases [1]. Since pre-industrial times in the early 20th century global temperatures have risen $1.2^{\circ} \mathrm{C}$ [2] alarmingly close to the $1.5^{\circ} \mathrm{C}$ cap set by politicians in the 2016 Paris agreement [3]. This results in more frequent extreme weather conditions such as flooding, droughts and storms. This effects the livelihoods of all people, especially populations in developing countries that are arguably less resilient to extreme weather. Along with extreme weather phenomena, global warming melts the polar ice caps causing the sea level to rise [1]. Australia is a coastal country with $85 \%$ of people living in coastal regions, with a sea level rise of $50 \mathrm{~cm}$, Australia will experience a 300 -fold increase in flooding events; infrastructure that floods once every 100 years will be flooded several time per year [4]. Due to human induced climate change, there is a need to investigate developing the built environment in a more sustainable manner.

The majority of apartments in Australia are constructed using a concrete and steel structure [5]. This is an issue as Kajaste and Hurme [6] state that 5-8\% of global $\mathrm{CO}^{2}$ emissions derive from cement production. Cement is the substance that binds to aggregate that in turn creates concrete. In recent years, a product known as Cross-laminate Timber (CLT) arose in the 1990s from Europe. CLT panels are made from boards that are glued side by side to another and layered at 90 degree angles [7]. This then forms one rigid panel typically 5-7 layers thick. CLT panels can be used as an alternate to concrete and steel to create the structure of an apartment building. There is a consensus that when a forest is sustainably managed, wood is carbon neutral. Trees remove carbon from the atmosphere through carbon sequestration [8]. Furthermore, In Chen's [9] life cycle assessment study of two 5 story buildings; one 
made of concrete and steel, one of CLT, it was found that the CLT building consumed $15 \%$ less energy than the concrete building. Constructing with CLT can act as a part solution to reducing $\mathrm{CO}^{2}$ emissions from the construction sector and assists us moving toward creating net-zero carbon buildings.

CLT buildings have become popular in Europe with Hundreds completed since the 1990s [10]. As at 2012 in North America, 4 manufacturers were operating [10]. New Zealand Company XLam Ltd. recently advised to the public their plans to open the first CLT factory in Australia [11]. The investment signals a demand for the product and technology outside of the foundational European stronghold CLT has. To date, in Australia two residential apartment buildings have been completed; Forte [12] \& The Gardens [13]. The Garden's 3000 cubic meters $\left(\mathrm{m}^{3}\right)$ of CLT panels were supplied from a company called Binderholz, based in Austria [14]. However, with local supply coming online in the coming years, this may open the gates to further development of CLT in Australia.

\subsection{Research Gap and Research Problem}

There is an abundance of research on CLT, the research has a focus on North America and Europe, with just several papers based in Australia. Research topics vary widely; from performance characteristics, sustainability characteristics, CLT perceptions, CLT design guide, barriers to growth to the outlook for CLT, In Espinoza's [15] article 'Cross-Laminated Timber: Status and Research Needs in Europe' gaps in future research needs were identified via surveys with industry professionals. Compatibility with building codes, availability of technical information, misconceptions, cost and market availability were the top-ranking research needs. Reviewing the literature, including Espinoza et al [15] article, a gap in research was identified; there is not an abundance of research that covers the comparative financial performance of CLT apartment buildings. From the developer perspective, land cost, construction cost and potential revenue are the primary feasibility variables to calculate before committing to a new development. Considering that, this research covered these aspects. This data could give confidence to the market for the wider adoption of CLT as an alternative to concrete and steel.

\subsection{Research Aims}

This research aimed to undertake a financial modelling analysis of a CLT building and compare it with a traditional concrete and steel structure to determine if there is an economic advantage. The findings from the research are of significance to fulfil a gap in current CLT research. As only a small amount of research covers the comparative financial performance of CLT from the developers perceptive. This research can be used as a reference for real estate developers looking to further understand the comparative profitability of CLT buildings in Australia. If the analysis reveals that the CLT building is efficacious in terms of the financial return, then this may be a catalyst to wider adoption of CLT in Australia. Research objectives include identifying and comparing;

1. The Total Development Cost.

2. The Development Profit.

3. The Development Margin.

4. The Return on Equity \& Equity Internal Rate of Return

\subsection{METHODOLOGY}

As indicated in the introduction, the study includes the analysis of two buildings. One that is currently under construction (reference) and one that is theoretically constructed of CLT (study). The study building was modelled using CLT as the primary structural material and the reference building was modelled using concrete and steel as the primary structural material. The reference case building was selected due to availability of data from my present industry role. Disclosure of building and location is not possible due industry privacy concerns. The study CLT case building was selected due to the site and architectural plans being able to accommodate a CLT application. This is elaborated on in section 3.2. 
The research methodology is mostly quantitative in nature, with a small qualitative element being the contribution of several major financial institutions and their ability to finance a CLT project and under what conditions. Comparing two buildings in terms of their final development margin, development profit, return on equity (ROE) and Equity Internal Rate of Return (IRR). The analysis was conducted on EstateMaster and Nitro software. EstateMaster is the industry standard adopted software used to model the financial performance of a development. Nitro is used to measure the quantity of CLT required.

The following financial factors; apartment revenue, build cost, professional fees, statutory fees, debt costs and time were compiled into a financial model using EstateMaster software to analyse the comparative financial performance of CLT versus concrete and steel.

This cost, time and profit based research assumes the same sales figures can be achieved with CLT compared to concrete and steel. This may not be the case. Further research will be needed to gauge market uptake and comparative revenue values to concrete and steel buildings. This would complete the final segment of the CLT financial model. This further academic research is needed to breakdown the final barrier and the fulfil the research priority related to revenue performance of CLT.

\subsection{Building Scope (reference)}

Defining the building scope of the study (CLT) and reference building (Concrete) assists to understand what the construction difference is. The reference building is a multi-story residential apartment building located in Sydney. It consists of 79 apartments across 3 buildings. Building A has 17 apartments across levels 1-7. Building $\mathrm{B}$ has 31 apartments across levels 3-8. Building $\mathrm{C}$ has 31 apartments across levels 2-7. The building has 2 levels of underground parking connecting between Building A and C. Level 3 is at ground level; each building is erected separately from the ground upward. The 2 basement levels have shoring, piling and shotcrete to retain the excavated area. From the slab on ground there are post tensioned concrete slabs on top of concrete and steel columns creating the structure. Level 3 is a podium slab sitting at ground level. The concrete and steel structure is then erected to 6/7 levels above ground. The internal walls dividing apartments are made from Hebel and the partition walls in the apartments are made from steel studs with insulation and plasterboard. The external façade is comprised of brick up to level 6/7 with fibre cement cladding and render completing the top levels of each building. The internal fit-out is a standard design with floating timber floors, carpet, tiles in bathrooms, with timber veneer look joinery throughout the kitchen and bathrooms. It is not necessary to detail the internal fit-out for the research as it remains the same between the reference and study building.

\subsection{Building Scope (Study)}

The study building has many of the same construction features as the reference, the main difference being the structural element from level 3 and above. Levels 1, 2 and 3 remain the same and have post tensioned concrete slabs up to ground level at level 3, where the podium slab sits. From the concrete podium slab at ground level, the CLT panels begin. Concrete and steel columns are removed and CLT load bearing walls are put in place instead, they support the level 4 CLT floor plate. This structural methodology continues up level 7/8 on all three buildings. From ground level and above all concrete and steel is removed and replaced by structural CLT panels for the floor plates and load bearing walls. Refer to Figure 1 for an example illustration of CLT construction methodology. The external façade remains the same with brickwork up to level 6/7 and fibre cement cladding to upper levels. Internal finishes also remain the same with fire rated plasterboard covering the CLT panels. The quality of the external and internal finish is identical to the reference building. This is important to achieve the assumption of same sales figures as the reference building. 


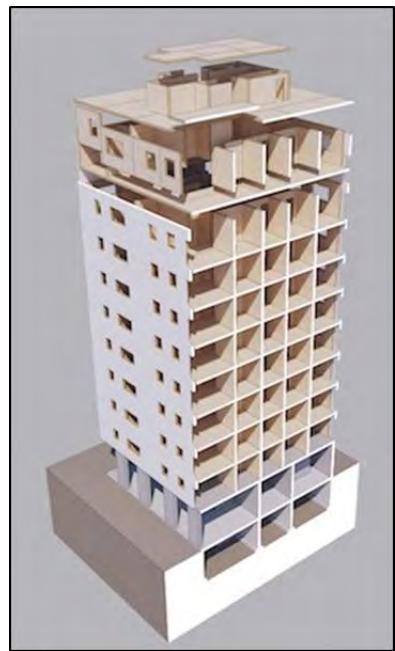

Figure 1. Cross-section of a CLT building. Grey area indicates concrete basement area, brown area indicates CLT floors and load bearing walls [16].

\subsection{Financial Appraisal Methodology}

The quantitative financial appraisal methodology adopted is the industry standard methodology practiced in the property development industry, as identified by Harvard [17]. The basic equation is Gross Revenue Less Total Development Cost equals Profit. Development Margin (\%) is Profit divided by Total Development Cost. The figures; development profit, development margin and Equity IRR are then used to appraise the development and its comparative financial performance.

The first part of the approach covers the revenue generated from apartment sales. In this research, the same revenue figures were assumed, as the internal finish quality is the same as the concrete and steel building, equal sales figures have a probable chance of being achieved. However, as identified previously, further research is needed to gauge market uptake and comparative revenue values to concrete and steel buildings to test this assumption.

Following on from revenue, the cost figures are analysed. Land value remained static between the two developments. Construction cost differed between the two buildings; this is due to the construction methodology changing as described in the previous section. The last variables that changed are construction program time, interest and land holding costs. These costs are reduced due to the reduced construction time identified in the following construction program section. Interest is charged per day on a capitalized basis on the amount of funds drawn from the bank facility. The funds drawn from the debt facility pay for the construction cost borne by the head contractor, along with part of the land settlement costs, council contributions and land holding costs. Of total development costs, the bank covers $80 \%$ of the cost through debt, that is then repaid at project completion once apartment buyers settle of their new apartments. As such, the reduced interest costs played a key role in changing the end development margin of the two projects. Land holding costs such a land tax and rates also changed due to the land changing hands from the developer to apartment purchasers' sooner.

As a rule of thumb, currently developers only move forward with a project if the development margin is greater than $20 \%$, some developers who are more risk adverse only accept greater than $25 \%$ [17]. 


\subsection{Construction Cost Methodology}

Construction cost methodology was calculated in one primary way. The reference building is built under a design and construct contract at a lump sum price, subject to variations, to a total price of $\$ 26,028,197.00$. The contract is broken into trade items such as; preliminaries, earthworks, concrete, services, painting and joinery. There are 48 trades, these are claimed on a month to month progressive basis as the work is completed on site. These 48 trades are broken down on a per level per building basis.

To calculate the cost to build with CLT instead of concrete, all trade items of reinforcement, formwork and concrete from level 3 upwards were removed. Hebel apartment dividing walls along with a large number of tracks, studs and insulation costs were removed from level 3 upwards as they were replaced by CLT. These items are under the plasterboard and lining trade. A supply and install rate for CLT at $\$ 1,600$ per $\mathrm{m}^{3}$ was supplied by Strongbuild. Strongbuild acts as a head contractor on CLT apartments, but can also deliver only the structural CLT element of a building as the sub-contractor. The price has been derived from market experience. A quantity take-off of $\mathrm{m}^{3}$ of CLT was performed to identify the quantity required, that was then applied to the supply and install rate and added into a revised trade value breakdown. 5-layer thick $(150 \mathrm{~mm})$ panels were used as structural loadbearing walls and 5 layer panels were used for the floors along with several $300 \mathrm{~mm}$ by $300 \mathrm{~mm}$ CLT beams for structural support when floors are stressed to span more than $5.5 \mathrm{~m}$. CLT layout design and assumptions were based off Mahlum et al's [18] construction report.

Finally, the preliminary trade item was reduced in accordance with the amount the construction program was reduced by, as identified in section 3.4. Preliminaries are mostly made up costs that are paid for on a time related basis. Such as; crane, scaffolding, site office, staff, electricity, plant, equipment and insurance. As such, these can be reduced in accordance with the reduction in construction program time. However, the reduction was conservative and not reduced exactly as per the construction time reduction, this accounts for some of the fixed costs under preliminaries.

By revising these trade items, the new contract construction cost figure was calculated. This figure was then worked into the financial model along with the other costs associated with the development to calculate the net development profit, development margin, ROE and Equity IRR.

\subsection{Debt Facility}

$80 \%$ of the total cost of the reference building is financed through a debt facility that is drawn down over the project life. Interest is paid on funds drawn, is it capitalized and paid at project completion when apartment buyers settle on their new apartments. CLT is a new product and has relatively unfamiliar construction methodology in Australia. Banks by nature are risk averse, and will thus change the interest rate on development finance considering perceived project risk. This risk could be altered because of sponsor track record, market conditions or type of project. To be sure the correct interest rate and LCR was applied to the study reference project financial model, I conducted minor surveys to major banks such as Commonwealth Bank of Australia and Australia and New Zealand Banking group.

The following questions are quantitative;

1. Can the current $6 \%$ interest rate be maintained? If not, what would it change to?

(This rate may increase due to CLT being an uncommon product in the Australian market. It will be assumed project sponsor remains the same with the CLT project).

2. Can the $80 \%$ LCR be maintained? If not, what would it change to?

(As banks may request extra equity to be injected to reduce their exposure to risk. This ratio may lower to $65-75 \%$, this results in further equity needing to be injected affecting the project ROE and Equity IRR).

\section{How many presales are needed before the debt facility is can be drawn?}


(Under the Facility Agreement, $100 \%$ of the total facility has to be covered by presales before utilization of any funds happens).

The final questions are to be qualitative; this will assist to identify unforeseen variables.

1. What is the bank's ability to finance the project?

(Finance might need to move to a lower tier bank due to the Australia's big four banks risk adverse nature).

\section{Will additional security on the debt facility be required?}

(Additional to; a general security agreement between bank and borrower, loan and interest guarantees from directors, first mortgage over subject property and tripartite agreement between the bank, borrower and builder (Builder's side deed)).

\section{What is the ability to provide first mortgages to apartments buyers?}

(The bank might request higher than $10 \%$ deposits on presales to reduce risk, or loan to value ratios (LVR) might be reduced for apartments buyers, this would then effect the ability of the developer to pre-sell apartments, as buyers may not want to buy a product with potential foreseen issues obtaining a mortgage to settle on their property. This would then affect the chance of the developer receiving finance, as banks need a set amount of presale contracts exchanged before they commit to financing the development and allow funds to be drawn).

\subsection{FINDINGS}

\subsection{Development Feasibility (Reference)}

Key parameters inputted to the reference building feasibility are the following;

- $\quad$ Sales revenue is $\$ 71,190,980$

- $\quad$ Land purchase is $\$ 12,025,020$

- Construction cost is $\$ 26,028,197$; this is the head contract lump sum price.

- Construction contingency is set at $5 \%$ of contract value, is it assumed $100 \%$ of contingency is used, taking a conservative approach.

- Professional fees to obtain DA, CC and take the project through construction process is at $\$ 2,590,544$.

- $\quad$ Council fees / Section 96 contributions are $\$ 2,387,836$; this is based off construction cost.

- Interest expense of $\$ 2,682,712$, this is based on a $6 \%$ interest rate on funds drawn from the debt facility.

Further inputs were modelled in the feasibility such as timing of cash inflows and outflows, administration costs, marketing costs, legal costs and authority fees. KPIs of the reference project are addressed in table 4.

\subsection{Development Feasibility CLT (Study)}

\subsubsection{Construction Program}

As mentioned previously, the construction program is one of the variables that was be reduced. The reference construction program for is 21 months, due for completion December 2017. FPI Innovations [19] indicated that the construction time of a CLT building is reduced by between $30-40 \%$ when compared with traditional concrete and steel constructions. Along with this, it was indicated a CLT level can be erected every 3 days, compared to approximately every 2 weeks for a post tensioned concrete slab. Construction time reduction resulted in a 15-month construction program, compared to a 21-month program, a 6-month reduction. This timing was worked into the financial model in EstateMaster. 


\subsubsection{Construction Cost Calculation}

The amount $\mathrm{m}^{3}$ of CLT required was calculated by measuring all CLT floor plates and load bearing walls on Nitro software. The $\mathrm{m}^{3}$ calculated was then applied to the supply and install rate of $\$ 1,600$ supplied by Strongbuild. This resulted in the total cost of the CLT trade, then applied to the revised total construction cost. Formwork, reinforcement and concrete costs were removed from level 4 upwards. $2,284 \mathrm{~m}^{2}$ of Hebel and 9,726.1 $\mathrm{m}^{2}$ of steels stud framing and insulation were removed as they were replaced with CLT. Preliminaries were reduced by $30 \%$ in line with the reduced construction program. Table 1 below indicates total amount and cost of CLT introduced. $3,098 \mathrm{~m}^{3}$ of CLT is needed at a total supply and install cost of $\$ 4,956,432$. The supply and install cost includes waste, cranage and transport logistics. Revision of the original construction cost results in a $2.64 \%$ increase in total construction cost.

The revised construction figure $\$ 26,715,582.60$ was worked into the feasibility model along with the reduced construction time to identify the effect it has on the Profit Margin and Equity IRR. Table 2 below illustrates the total construction cost changes, how much each trade increased or decreased by with the introduction of CLT and removal of concrete and steel.

Table 1. CLT Cost Calculation

\begin{tabular}{cccc}
\hline & $\mathrm{M}^{3}$ & Cost & Total \\
\hline Floors & 1325.00 & $\$ 1,600.00$ & $\$ 2,120.025 .60$ \\
Walls & 1772.75 & $\$ 1,600.00$ & $\$ 2,836,406,40$ \\
Total & $\mathbf{3 0 9 7 . 7 7}$ & $\mathbf{\$ 1 , 6 0 0 . 0 0}$ & $\mathbf{\$ 4 , 9 5 6 , 4 3 2 . 0 0}$ \\
\hline
\end{tabular}

Table 2. Revised Contract Trade Item Changes (Reference to Study)

\begin{tabular}{ccccc}
\hline Description & Original Value & Adjusted Value & $\$$ Variation & $\%$ Variation \\
\hline Preliminaries & $\$ 4,986,185.00$ & $\$ 3,835,526.92$ & $-\$ 1,150,658.08$ & $-30 \%$ \\
CLT floors & & $\$ 2,120,025.60$ & $\$ 2,120,025.60$ & $100 \%$ \\
CLT walls & & $\$ 2,836,406.40$ & $\$ 2,836,406.40$ & $100 \%$ \\
Formwork & $\$ 2,131,829.00$ & $\$ 818,276.25$ & $-\$ 1,313,552.75$ & $-161 \%$ \\
Reinforcement & $\$ 1,408,942.00$ & $\$ 686,430.13$ & $-\$ 722,511.87$ & $-105 \%$ \\
Concrete & $\$ 1,723,598.00$ & $\$ 997,010.90$ & $-\$ 726,587.10$ & $-73 \%$ \\
Plasterboard \& Hebel & $\$ 1,694,635.00$ & $\$ 1,338,898.40$ & $-\$ 355,736.60$ & $-27 \%$ \\
Zero Change Items & $\$ 14,083,008.00$ & $\$ 14,083,008.00$ & $\$ 0.00$ & $0.0 \%$ \\
Revised Contract Value & $\mathbf{\$ 2 6 , 0 2 8 , 1 9 7 . 0 0}$ & $\mathbf{\$ 2 6 , 7 1 5 , 5 8 2 . 6 0}$ & $\mathbf{\$ 6 8 7 , 3 8 5 . 6 0}$ & $\mathbf{2 . 6 4 \%}$ \\
\hline
\end{tabular}

\subsubsection{Debt Facility}

Semi-structured interviews were conducted with two major banks. The questions, assumptions and possible changes identified in methodology section 3.6 were posed to banks. All but one quantitative characteristics of the construction facility conditions would remain the same. The Interest rate of $6 \%$ and LCR of $80 \%$ could be maintained with the use of CLT as the construction methodology. Both banks could provide finance to the project, assuming same project sponsor. However, the variable that changed was a construction contingency of $10 \%$ needed to be carried forward in the feasibility instead of the current 5\% contingency. This revised figure was added to the study CLT building feasibility model. The feasibility model assumes the full 5 or $10 \%$ contingency is used, the effect it has on the bottom line figures is substantial. Analysis of this is found in the discussion section. Further qualitative commentary provided by banks was the following; 
- $\quad$ "The posed builder would need to show a track record of working with CLT.

- Consideration to whether this type of construction required higher "off site" funding (i.e. down payments for materials not yet delivered to site and installed) and whether the developer had the financial resources to fund those short term.

- Banks typically only allow drawdown of funding once materials are incorporated into the works which removes any risk to the bank associated with failure by the subcontractor to perform despite being paid upfront, and removes any" retention of title" type issues when considering what is and is not captured by our security position

- The primary concern is payment for the CLT prior to deliver to site as payment may be required during off site manufacturing. Assuming the bank can understand the risk, typical leverage ratios could remain.

- $\quad$ Presale requirements remain the same before the facility can be drawn, $100 \%$ debt and interest coverage from presale value.

- $\quad$ The proposed metrics would be within our appetite however, a deeper understanding around the following (but not limited to) is required: Proposed Head Contractor and their financial and technical capacity, Developers past track record, financial capacity (including liquidity) and project team, Quality of Pre-sales, Immediate supply in the area

- Typical security structure would apply and include: Project security, Sponsor or Directors limited personal guarantees.

- If payment is required for the CLT prior to deliver on site, the bank will require bank guarantees issued by the head contractor until deliver and installation is complete.

- $\quad$ Mortgage lending is a highly regulated product at the moment. There is the responsible lending act which outlines the key criteria the banks need to follow as part of the assessment process for mortgage lending, These include capacity to service at a minimum interest rate of $7.25 \%$. Loan to Value ratios have been reduced with each bank slightly different. Investor loans are more difficult to obtain particularly on an interest only. Owner occupiers on a principal and interest arrangement with LVR of $80 \%$ or less will find it least restrictive compared to investors".

4.2.4 Land Holding Costs and Interests Costs

Table 3. Interest and Holding Cost Reductions

\begin{tabular}{cccl}
\hline & Reference & CLT (Study) & \multicolumn{1}{c}{ Comment } \\
\hline $\begin{array}{c}\text { Land Holding Costs } \\
\text { (Land Tax and Rates) }\end{array}$ & $\$ 159,800$ & $\$ 131,600$ & $\begin{array}{l}\text { Reduction due to land changing hands from } \\
\text { developer to apartment purchasers quicker. }\end{array}$ \\
Interest Expense & $\$ 2,682,712$ & $\$ 2,033,399$ & $\begin{array}{l}\text { Reduction due to less annual capitalized } \\
\text { interest paid on debt facility, debt repaid } \\
\text { quicker as settlement occurs 6 months prior } \\
\text { to reference building. }\end{array}$ \\
\hline
\end{tabular}

\subsubsection{Development Feasibility CLT (Study)}

The revised CLT feasibility model variables identified above were inputted to EstateMaster to model the effects they would have on the key performance indicators. Refer below for revised performance indicators. Table 4 exhibits a comparison of performance indicators versus the original reference building. Equity injection increased, development profit, development margin and ROE decreased. However, the Equity IRR increased. These changes are discussed in the following discussion section. 


\subsection{Feasibility Comparison}

Table 4. Reference versus Study CLT (KPIs)

\begin{tabular}{lcccl}
\hline & Reference & CLT (Study) & Variance & \multicolumn{1}{c}{ Comment } \\
\hline Equity Injected & $\$ 9,155,459$ & $\$ 9,591,991$ & $+4.77 \%$ & Due to higher contingency \\
Development Profit & $\$ 15,422,695$ & $\$ 13,889,852$ & $-9.94 \%$ & needed in feasibility, increased \\
$\begin{array}{l}\text { Development Margin } \\
\text { ROE (Return on Equity) }\end{array}$ & $27.65 \%$ & $24.24 \%$ & $-12.33 \%$ & construction cost, less interest \\
& $168.45 \%$ & $144.81 \%$ & $-14.03 \%$ & and holding costs. \\
$\begin{array}{l}\text { Equity IRR } \\
\text { (Internal Rate of Return) }\end{array}$ & $\mathbf{3 3 . 4 6 \%}$ & $\mathbf{3 6 . 5 8 \%}$ & $\mathbf{+ 9 . 3 2 \%}$ & $\begin{array}{l}\text { Increase IRR due to reduced } \\
\text { construction time }\end{array}$ \\
\hline
\end{tabular}

\subsection{DISCUSSION AND CONCLUSION}

To begin with, the first and arguably the most important factor that changed in the feasibility model was the construction cost. The construction cost recalculation resulted in a $2.64 \%$ increase in total construction cost. Several points need to be considered. $3,100 \mathrm{~m}^{3}$ of CLT was estimated to be required to build the structure of the study CLT building. This $\mathrm{m}^{3}$ estimate is roughly in line with the $3000 \mathrm{~m}^{3}$ of CLT required to build the 101 apartment development by BlueCHP [13] (The Gardens, Campbelltown). This development is of similar size and design, also comprised of 3 separate buildings connected by an underground car park with CLT applied from concrete podium ground slab upwards [20]. This provides some certainty that the measurement methodology to estimate CLT required at the study building was correct. Further validating this calculation was the similar construction cost increase found, Smith [21] found CLT compared to concrete resulted in a $11.9 \%$ increase in cost, while this subject research found there was an $8.64 \%$ increase in cost, both increases were exclusive of the preliminaries reduction. This was done to compare cost more accurately.

To improve the validity of the CLT measurement, engaging a quantity surveyor to revise and audit the measurement would result in a more accurate CLT measurement. Further to this, CLT load bearing walls and floor plates were set out in accordance with Mahlum et al's [18] construction guide. To improve the validity of the assumptions made for this research, engaging a structural engineer and architect to revise the design and structural assumptions would also improve the validity of construction methodology. Additionally, a fire and acoustic engineer would be of assistance to ensure BCA requirements are met. Further improving research accuracy, the use Building Information Modelling (BIM) technology would assist modelling CLT construction methodology and $\mathrm{m}^{3}$ required. Considering these points, the current research leaves room for improvement in terms of accuracy, buildability, technology integration and meeting statutory requirements with CLT application in lieu of concrete and steel. However, the research process and methodology undertaken is of value, as if done with increased accuracy in collaboration with other industry professionals it can be used by property industry professionals.

Calculating the revised construction cost was one of the major components needed for the feasibility model. However, several other variables were adjusted. Construction cost was inputted along with the reduced construction time of 15 months as opposed 21 months. This then results in an adjustment in the timing of revenue inflow. Pre-sales settlements are triggered as soon as Occupation Certificate is received and the Strata Plan is registered with Land and Property information (LPI), which happens directly after the construction is completed. The six-month decrease in timing of revenue inflow has a dramatic effect on the Equity IRR. The Equity IRR increased from $33.46 \%$ to $36.58 \%$. Equity shareholders are repaid their equity plus margin substantially quicker resulting in an improved Equity IRR. 
Due to this reduced construction time resulting in an earlier settlement date, interest and land holding costs are reduced. As seen in table 3, land holding costs are comprised of land tax and rates, as the land changes hands from the developer to the purchaser quicker, this results in reduced holding costs of $\$ 28,200$. The same logic is applied to interest costs, interest on development finance is charge per annum on a capitalized basis of funds drawn. Funds are drawn on March 15 to settle on the land and drawn progressively from March 2016 to December 2017 to finance construction. With CLT construction, construction funds are drawn from March 2016 to June 2017 instead, then repaid that same month. This results in a reduction of $\$ 649,313$ in interest costs. The construction program reduction seen with CLT results in costs savings for time related cost components.

It is important to note, interviews with banks were highly valuable to confirm three key feasibility inputs were correct. Confirmation that the correct interest rate was being applied to development finance, and that the correct LCR was being applied to calculate the equity injection required. Both interviewees confirmed a total $6 \%$ interest rate could be applied to the study CLT development and the $80 \%$ LCR could be maintained. However, one input did change which was construction contingency to be carried forward, this is discussed in the following paragraphs.

Several qualitative factors were mentioned; these are important to note for future reference. Both interviewees indicated that to finance the development they would need to have a detailed understanding of the contractor's track record, financial capacity and technical ability to build with CLT. CLT panels are prefabricated, fabrication could take place as far away as Austria. Both banks mentioned concern over payment of CLT prior to delivery on site, as the bank can usually only fund materials fixed on site, this removes any risk to the bank associated with failure by the subcontractor to perform. Off-site funding may be required, either the contractor or developer will have to fund down payments for CLT supply. Whether or not the developer/contractor has the financial capacity to fund this short term will need to be explored and detailed, then documented under the head construction contract to ensure banks understand the risk involved before financing.

Construction values increased in the feasibility along with the construction contingency carried forward. This was identified from the interviews with banks, a 10\% contingency (based of total construction cost) instead of 5\% needs to be carried forward. This resulted in total development cost (TDC) increasing from $\$ 48,843,336$ to $\$ 50,376,178$. As the revenue variable remained the same and TDC increased, the development profit and development margin decreased from $\$ 15,422,695$ to $\$ 13,889,852$ and $27.65 \%$ to $24.24 \%$ respectively. Along with this, as the TDC increased, the bank requires $20 \%$ TDC to be financed with equity, equity injection increased from $\$ 9,155,459$ to $\$ 9,591,991$; additional shareholder capital is required with the CLT project. These figures working together resulted in a decreased ROE, reducing from $168.45 \%$ to $144.81 \%$. However, it is important to note, even though all these figures reduced, the Equity IRR increased, this is due to the reduced construction time. Depending on investor objectives and requirements, one may opt for a higher Equity IRR as their capital is disbursed quicker allowing them to allocate the capital to a new investment sooner rather than having it tied up for an additional 6 months before being free for new allocation. Alternatively, if this is just a one off investment for a shareholder, it is probable they would opt for the original reference building investment as the overall ROE is greater.

It can be concluded, if two buildings have the same characteristics as the reference and study building, building with CLT may result in less development profit, development margin, ROE, but an increased Equity IRR due to a reduced investment timeline. The option an investor will opt for depends largely on their investment mandate. A greater total one off investment return by way of an increased ROE (reference), or a higher annual return by way of an increased Equity IRR (CLT study). 


\section{REFERENCES}

[1] Solomon, S., Qin, D., Manning, Z., Chen, M., Marquis, K.B. Averyt, Tignor, M. Miller, H.L. (2007). Climate Change 2007: The Physical Science Basis. Contribution of Working Group I to the Fourth Assessment Report of the Intergovernmental Panel on Climate Change. IPCC. Cambridge University Press, Cambridge, United Kingdom and New York, NY, USA.

[2] The Economist (2016). The state of the climate in 2016. [online] Available at: http://www.economist.com/blogs/graphicdetail/2016/11/global-warming [Accessed 9 Mar. 2017].

[3] UNFCCC (2017). The Paris Agreement. [online] Available at: http://unfccc.int/paris_agreement/items/9485.php [Accessed 9 Mar. 2017].

[4] Department of Environment and Energy. (2017). Sea level. [online] Available at: http://www.environment.gov.au/climate-change/climate-science/climate-change-future/sea-level [Accessed 9 Mar. 2017].

[5] Chandler, D. (2015). What Does Australia Make for Construction These Days?. Sourceable. [online] Available at: https://sourceable.net/what-does-australia-make-for-construction-these-days/ [Accessed 25 Mar. 2017].

[6] Kajaste, R. and Hurme, M. (2016). Cement industry greenhouse gas emissions - management options and abatement cost. Journal of Cleaner Production, 112, pp.4041-4052.

[7] Laguarda Mallo, M. and Espinoza, O. (2015). Awareness, perceptions and willingness to adopt Cross-Laminated Timber by the architecture community in the United States. Journal of Cleaner Production, 94, pp.198-210.

[8] Laguarda Mallo, M. and Espinoza, O. (2014). Outlook for Cross-Laminated Timber in the United States. BioResources, 9(4).

[9] Chen, Y.J. (2012). Comparison of Environmental Performance of a Five-storey Building Built with Cross-laminated Timber and Concrete (Thesis). Department of Wood Science.

[10] Mohammad, M., Gagnon, S., Douglas, K. and Podesto, L. (2012). Introduction to Cross Laminated Timber. WOOD DESIGN FOCUS, 22(2).

[11] Lenaghan, N. (2016). XLam opens Aust's first factory for CLT. AFR. [online] Available at: http://www.afr.com/real-estate/xlam-opens-austs-first-factory-for-clt-20160520-gp079v [Accessed 13 Mar. 2017].

[12] El Forte (2017). El Forte. [online] Available at: http://www.forteliving.com.au/ [Accessed 9 Mar. 2017].

[13] The Gardens Blue CHP. (2017). The gardens. [online] Available at: http://www.thegardensbluechp.com.au/ [Accessed 9 Mar. 2017].

[14] Lenaghan, N. and Bleby, M. (2016). Timber towers take shape fast in Campbelltown. AFR. [online] Available at: http://www.afr.com/real-estate/timber-towers-take-shape-fast-in-campbelltown20160714-gq51mj [Accessed 13 Mar. 2017].

[15] Espinoza, O., Rodriguez Trujillo, V., Laguarda Mallo, M. and Buehlmann, U. (2015). CrossLaminated Timber: Status and Research Needs in Europe. BioResources, 11(1).

[16] Marticorena, S. (2017). CLT Construction. [Blog] Fat Pencil Studio. Available at: http://fatpencilstudio.com/clt-construction/ [Accessed 25 Mar. 2017].

[17] Harvard, T. (2014). Financial feasibility studies for property development. 1st ed. New York: Routledge, pp.17-18. 
[18] Mahlum, Walsh Construction Co, Coughlin Porter Lundeen, (2014). CLT Feasibility Study, A Study of Alternative Construction Methods in the Pacific Northwest. [online] Portland. Available at: http://www.seattle.gov/dpd/cs/groups/pan/@pan/documents/web_informational/p2174864.pdf [Accessed 27 Mar. 2017].

[19] FPI Innovations, (2017). The Value Proposition for Cross-Laminated Timber. [online] FPI Innovations. Available at: http://www.fpac.ca/publications/Value-CLT2011\%20NABC\%20anaylisfinal.pdf [Accessed 27 Mar. 2017].

[20] Bleby, M. (2017). Timber CLT construction the only way to build denser housing and cut emissions. AFR. [online] Available at: http://www.afr.com/real-estate/timber-clt-construction-theonly-way-to-build-denser-housing-and-cut-emissions-20170306-gury9z [Accessed 03 Jun. 2017].

[21] Smith, R. (2017). MBM - Commercial and Residential Sectors Traditional Concrete Construction vs. Timber Construction - Which is cheaper? [presentation].

\section{UNCITED REFERENCES - LITERATURE REVIEW}

[22] AFS, (2017). Home. [online] Forestrystandard.org.au. Available at: http://www.forestrystandard.org.au/ [Accessed 27 Mar. 2017].

[23] AWC, (2012). Preliminary CLT Fire Resistance Testing Report. [online] American Wood Council. Available at: http://www.awc.org/Code-Officials/2012-IBC-Challenges/Preliminary-CLT-FireTest-Report-FINAL-July2012.pdf. [Accessed 25 Mar. 2017].

[24] Calkins, M. (2009). Materials for sustainable sites. 1st ed. Hoboken: Wiley.

[25] Carre, A. and Crossin, E. (2015). A comparative Life Cycle Assessment of Two Multi Storey Residential Apartment Buildings. Sydney: Forest \& Wood Products Australia.

[26] Ding, G. and Forsythe, P. (2017). A Study Comparing the Global Warming Potential of Timber and Reinforced Concrete Construction in Office and Apartment Buildings. Sydney: Forest \& Wood Products Australia.

[27] Dunn, A. (2015). Final Report for Commercial Building Costing Cases Studies - Traditional Design versus Timber Project. Sydney: Forest \& Wood Products Australia.

[28] Durlinger, B., Crossin, E. and Wong, J. (2013). Life Cycle Assessment of a cross laminated timber building. Sydney: Forest \& Wood Products Australia.

[29] Forest and Wood Products Australia, (2012). Massive Timber Construction Systems: Crosslaminated Timber (CLT), Technical Design Guide. Sydney: Forest and Wood Products Australia Limited., pp.11-14.

[30] Friquin, K., Grimsbu, M. and Hovde, P. (2010). Charring rates for cross-laminated timber panels exposed to standard and parametric fires. In: World Conference on Timber Engineering. pp.20-24.

[31] Hampton, A. (2010). Thermal Mass and Insulation for Temperate Climates. Environmental Design Guide Journal, [online] 65. Available at:

http://environmentdesignguide.com.au/media/misc\%20notes/EDG_65_AH.pdf

[32] IBC, (2012). International Building Code. 4th ed. p.Chapter 7: Fire-resistance-rated Construction.

[33] Jowett, O. (2011). The thermal behaviour of cross-laminated timber construction and its resilience to summertime overheating. In: PLEA 2011-the 27th Conference on Passive and Low Energy Architecture. pp.339-344.

[34] Kremer, P. and Symmons, M. (2016). Overcoming Psychological Barriers to Widespread Acceptance of Mass Timber Construction in Australia. Forest \& Wood Products Australia Limited.

[35] Kuilen, J., Ceccotti, A., Xia, Z. and He, M. (2011). Very Tall Wooden Buildings with Cross Laminated Timber. Procedia Engineering, 14, pp.1621-1628. 
[36] Lehmann, S. (2012). Sustainable Construction for Urban Infill Development Using Engineered Massive Wood Panel Systems. Sustainability, 4(12), pp.2707-2742.

[37] NSW govt. (2017). Department of Planning and Environment - Population projections. [online] Planning.nsw.gov.au. Available at: http://www.planning.nsw.gov.au/projections [Accessed 25 Mar. 2017].

[38] OECD, (2012). OECD environmental outlook to 2050: the consequences of inaction. International Journal of Sustainability in Higher Education, 13(3).

[39] Oneil, E. and Lippke, B. (2017). Integrating products, emission offsets, and wildfire into carbon assessments of inland northwest forests. Wood Fiber Science, 42(CORRIM Special Issue), pp.144164.

[40] Profile.id, (2017). Household size | City of Sydney | profile.id. [online] Profile.id.com.au. Available at: http://profile.id.com.au/sydney/household-size [Accessed 25 Mar. 2017].

[41] Quenneville, P. and Morris, H. (2007). Japan Kobe Earthquake Shake Table Simulation, Earthquake Performance of Multi-storey Cross Laminated Timber Buildings. NZ TIMBER DESIGN JOURNAL, [online] 15(4). Available at: https://www.scribd.com/document/270113307/Earthquake-Performance-of-Multi-Storey-CLTBuilding-Quennevile-Morris-Kobe-Shake-Table1 [Accessed 26 Mar. 2017].

[42] Schmidt, J. and Griffin, C. (2013). Barriers to the design and use of cross-laminated timber structures in high-rise multi-family housing in the United States. 1st ed. Boca Raton, Florida: CRC Press, pp.2225-2231.

[43] Skogstad, H., Gullbrekken, L. and Nore, K. (2011). Air leakages through cross laminated timber (CLT) constructions. NSB 2011 9th Nordic Symposium on Building Physics Proceedings : volume 1,1 .

[44] Steiger, R. and Gülzow, A. (2010). Validity of bending tests on strip-shaped specimens to derive bending strength and stiffness properties of cross-laminated solid timber (X-lam). The Future of Quality Control for Wood and Wood Products. 